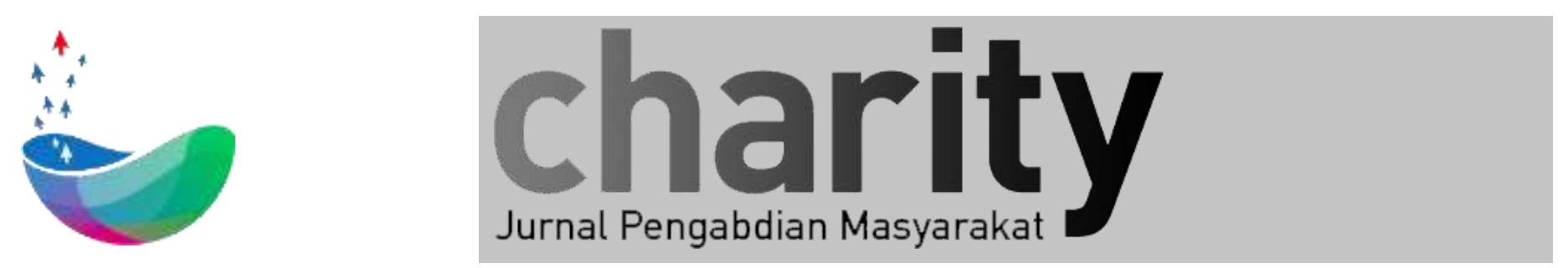

\title{
MEDIA KAMPANYE PEMELIHARAAN ALIRAN SUNGAI CITARUM DI DESA SUKAMUKTI KECAMATAN KATAPANG KABUPATEN BANDUNG
}

\author{
${ }^{1}$ Program Studi Ilmu Komunikasi, Fakultas Komunikasi dan Bisnis, Universitas Telkom
${ }^{2}$ Program Studi Ilmu Komunikasi, Fakultas Komunikasi dan Bisnis, Universitas Telkom
${ }^{3}$ Program Studi Ilmu Komunikasi, Fakultas Komunikasi dan Bisnis, Universitas Telkom
${ }^{4}$ Program Studi Ilmu Komunikasi, Fakultas Komunikasi dan Bisnis, Universitas Telkom
${ }^{5}$ Program Studi Teknik Informatika, Fakultas Informatika, Universitas Telkom
${ }^{6}$ Program Studi Diploma 3, Faklutas Teknik Telekomunikasi, Universitas Telkom
}

Reni Nuraeni ${ }^{1}$, Dini Salmiyah ${ }^{2}$, Idola Perdini Putri ${ }^{3}$, Ratih Hasanah ${ }^{4}$, Gede Agung Ary. W ${ }^{5}$, Yuyun Siti Rohmah ${ }^{6}$

* rezn_ns@yahoo.com, dinidjohan@gmail.com, Idolaperdiniputri@telkomuniversity.co.id, ratihhasanah@telkomuniversity.ac.id, yuyunsr@tass.telkomuniversity.ac.id, degunk@telkomuniversity.ac.id

\section{INFO ARTIKEL}

Diterima 26 Juli 2019

Direvisi 2 Agustus 2019

Disetujui 30 Agustus 2019

Tersedia Online 09 September 2019

\begin{abstract}
ABSTRAK
Sungai Citarum sebagai sungai terkotor di dunia menimbulkan kekhawatiran tentang perusakan alam di Indonesia. Aliran sungai ini menjadi nafas kehidupan bagi masyarakat Jawa Barat dan DKI Jakarta. Berbagai problematika muncul dari sungai CItarum, mulai dari konflik masyarakat, pemerintah hingga donor. Usaha untuk mevitalisasi sungai ini sudah ada sejak tahun 2004, namun hingga saat ini kualitas sungai ini masih memprihatinkan. Dalam upaya memperbaiki kualitas Sungai Citarum diperlukan strategi komunikasi kepada masyarakat melalui media kampanye pemeliharan aliran Sungai Citarum. Lokasi yang dijadikan objek dalan pengabdian masyarakat adalah Desa Sukamukti Kecamatan Kabupaten Bandung. Foto dan video dari kegiatan membersihkan lingkungan merupakan media yang digunakan sebagai salah satu sarana sosialisasi dalam rangka memberikan informasi kepada warga dalam hal kebiasaan membuang sampah sampai pada kegiatan membersihkan lingkungan yang dapat diakses melalui instagram.
\end{abstract}

Keyword: Citarum Harum, Media Kampanye, Instagram

Korespondensi:

Direktorat Penelitian dan Pengabdian Masyarakat, Universitas Telkom

Jl. Tele komunikasi No. 1, Terusan Buah Batu, Bandung, 40257 Indonesia.

E-mail : charity@telkomuniversity.ac.id

ORCID ID: 0000-0003-1317-0503

Penulis Pertama: Reni Nuraeni

https://doi.org/10.25124/charity.v2i1.2062

Paper_reg_number 2062 @ T The Authors. Published by Directorate of Research and Community Service, Telkom University.

This is an open access article under the CC BY-NC 4.0 license (https://creativecommons.org/licenses/ by-nc/4.0/) 


\section{Pendahuluan}

Kondisi lingkungan hidup dari hari ke hari semakin memprihatinkan., Kerusakan ekosistem di Indonesia bertambah jumlahnya dan sejumlah persoalan lingkungan hidup masih menjadi pekerjaan rumah yang membutuhkan penyelesaian. Persoalan ini menjadi sangat krusial karena menyangkut kualitas kehidupan di masa datang (https://nasional. sindonews.com).

Kerusakan lingkungan hidup yang selama terjadi ini banyak mengakibatkan bencana alam seperti sampah, banjir, sungai tercemar, pemanasan global. Pencemaran udara, rusaknya ekosistem laut, sulitnya ir bersih kerusakan hutan, abrasi, dan pencemaran tanah.

Sampah merupakan masalah yang dari hari ke hari semakin sulit diselesaikan dan semakin meluas dampaknya karena masalah sampah ini bukan hanya berdampak pada kesehatan saja akan tetapi pada bencana yang diakibatkan dengan volume sampah yang semakin bertambah.

Indonesia termasuk ke dalam 10 besar negara dengan jumlah penduduk terbanyak di dunia. Hal ini tak pelak menimbulkan sejumlah persoalan lanjutan, di antaranya adalah produksi sampah dan pembuangannya. Menurut data Kementerian Lingkungan Hidup dan Kehutanan, Indonesia memproduksi sampah hingga 65 juta ton pada 2016. Jumlah ini naik 1 juta ton dari tahun sebelumnya (https://nasional.sindonews.com).

Sulitnya solusi untuk menanggulangi permasalahan sampah bukan hanya fasilitas pembuangan yang sampah yang tidak maksimal tetapi juga kebiasaan masyarakat yang membuang sampah sembarangan.

Kebiasaan masyarakat membuang sampah sembarangan merupakan masalah terberat karena mengubah dan menghentikan kebiasaan ini memerlukan proses dan waktu yang lama, tetapi kalau tidak dimulai saat ini permasalahan sampah akan menjadi sangat besar dan kompleks.

Sungai Citarum juga tercemar limbah domestik yang dihasikan masyarakat, mulai dari sampah rumah tangga hingga kotoran manusia. Jumlah sampah rumah tangga sebanyak 20.462 ton/hari, 71 persen di antaranya tidak terangkut sampai ke tempat pembuangan akhir (TPA). Sebanyak 35.5 ton/hari kotoran manusia dan 56 ton/hari kotoran hewan/ternak juga dibuang langsung ke Sungai Citarum. Citarum merupakan sungai terpanjang dan terbesar di propinsi Jawa barat dan sangat mempengaruhi kehidupan masyarakat disekitarnya (http://www.greenpeace.org).

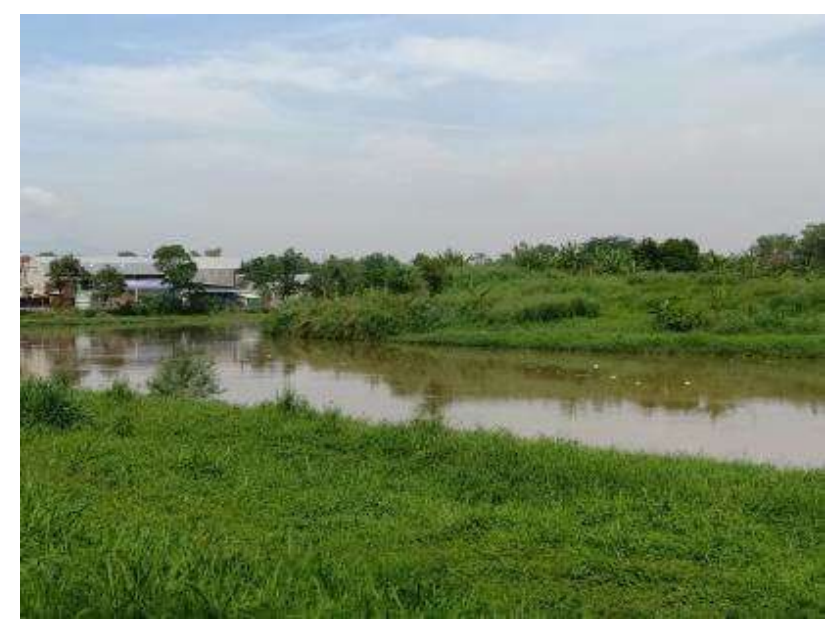

Gambar 1.1Aliran Sungai Citarum Desa Sukamukti 
Seperti yang diberitakan di berbagai media massa, telah terlaksananya program Citarum Bestari yang di laksanakan berbagai pihak seperti yang dilakukan oleh pemerintahan. Namun pada kenyataannya program tersebut hanya berfokuskan kepada pembersihan sungai Citarum akan tetapi tidak memperhatikan daerah diekitar sungai tersebut. Disaat warga sudah mengurangi pembuangan sampah di sungai, namun pemerintah tidak mengarahkan kemana sampah-sampah tersebut harus dibuang.

Sungai Citarum merupakan sumber penghidupan bagi 28 juta penduduk baik yang ada di Jawa Barat maupun yang ada diDKI Jakarta. Namun kondisi Citarum saat ini sakit, akibat sampah dan limbah.90\% industri bahkan tidak memiliki Instalasi Pengolahan Air Limbah (IPAL). Belum lagi volume sampah rumah tangga yang terus bertambah membebani sungaiCitarum, serta masih banyak masyarakat yang membuang sampah ke aliran sungai ini (http://bbksdajabar.ksdae.menlhk.go.id)

Program Citarum Harum merupakan program pemerintah yang merupakan lanjutan dari program Citarum Bestari yang didukung dengan terbitnya Peraturan Presiden Republik Indonesia Nomor 15 Tahun 2018 tentang Percepatan Pengendalian Pencemaran dan Kerusakan daerah aliran Sungai Citarum.

Melalui Peraturan Presiden Republik Indonesia Nomor 15 Tahun 2018 ini, Pemerintah membentuk Tim Satuan Tugas (Satgas) Pengendalian Pencemaran dan Kerusakan DAS Citarum yang isinya merupakan beberapa Kementerian dan Lembaga Pemerintah. Tugas dari Satgas sendiri meliputi Sosialisasi dan edukasi kepada masyarakat tentang kondisi DAS Citarum saat ini, penanganan limbah dan pemulihan ekosistem, relokasi masyarakat yang terdampak DAS Citarum, koordinasi data dan informasi, melakukan inovasi sesuai dengan perkembangan Imtek, perberdayaan masyarakat, dan pencegahan serta penindakan hukum (http://www.indonesiabaik.id).

Pemprov Jabar akan segera menyelesaikan upaya normalisasi Sungai Citarum seiring terbitnya Peraturan Presiden Nomor 15 Tahun 2018 tentang Percepatan Pengendalian Pencemaran dan Kerusakan Daerah Aliran Sungai Citarum. Keberhasilan Program Citarum Harum tidak akan bisa berkelanjutan tanpa adanya keterlibatan seluruh elemen masyarakat Jawa Barat, khususnya tindakan nyata dari insan pendidikan tinggi (http://unpar.ac.id/mewujudkan-citarum-harum).

Permasalahan ini dapat didasari oleh beberapa faktor baik faktor internal maupun faktor eksternal seperti faktor pendidikan. Banyaknya warga yang memiliki tingkat pendidikan yang rendah membuat mereka kurang paham atas apa yang harus dilakukan. Beberapa warga ada yang memilih untuk mengelola kembali sampah-sampah yang mereka hasilkan akan tetapi banyak warga yang tidak mengetahui caranya dan ada juga yang tidak mempedulikan bagaimana mereka membuang sampah sembarangan dan membakar sampahsampah tersebut. Selain faktor pendidikan, faktor sosial ekonomi juga sangat mempengaruhi.

Kurangnya kesadaran dan kepedulian masyarakat tentang bahayanya membakar sampah, melakukan penumpukan sampah ataupun kurangnya kesadaran masyarakat yang masih membuang sampah ke sungai. Mereka yang tidak tahu akibat yang akan didapatkan membuat mereka akan tetap melakukan hal tersebut jika tidak di sadarkan.

Latar belakang warga yang rata-rata mendapatka penghasilan yang rendah membuat mereka juga tidak dapat membayar biaya kebersihan atau melakukan usaha lainnya untuk mengelolah sampah-sampah tersebut. Sementara faktor eksternal seperti tidak adanya tidak tersedianya tempat sampah, ketidakmampuan membayar petugas kebersihan untuk mengangkut sampah ke tempat pembuangan akhir menjadi akar masalah yang perlu di atasi. 


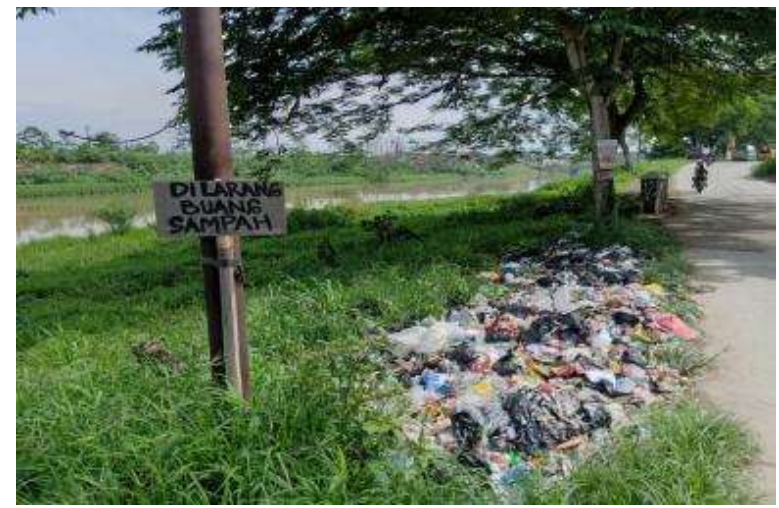

Gambar 1.2 Pembuangan Sampah Liar di Bantaran Sungai Citarum

Perubahan perilaku tidak membuang sampah di sungai dapat berkontribusi signifikan terhadap upaya revitalisasi Sungai Citarum. Hal ini akan berdampak positif bagi kelestarian sungai Citarum (https://tirto.id).

Edukasi dalam hal memberikan informasi agar mastarakat tidak membuang sampah ke sungai citarum atau anak sungai citarum ini merupakan hal penting yang harus segera dilakukan. Edukasi membuang sampah ini dapat dilakukan dengan berbagai kegiatan salah satunya melalui media kampanye. Warga masyarakat sering membuang sampah ke aliran sungai, atau bahkan membuang sampah Tempat Pembuangan Sampah (TPS) di lingkungan tempat tinggal masyarakat atau dibantaran aliran Sungai Citarum.

Edukasi pemberian informasi dilakukan dengan cara membuat media kampanye. Kampanye adalah aktivitas komunikasi yang ditujukan ntuk memengaruhi orang lain agar ia memiliki wawasan, sikap dan perilaku sesuai dengan kehendak atau keinginan penyebar atau pemberi informasi (Cangara, 2011:223). Kampanye pada dasarnya adalah penyampaian pesan -pesan dari pengirim kepada khalayak. Pesan-pesan tersebut dapat disampaikan dalam berbagai bentuk mulai dari poster, spanduk, papan reklame, pidato, iklan diskusi,sehingga selebaran (Venus , 2004).

Pada kegiatan ini kampanye dilakukan dengan melakukan kegiatan kebersihan yang melibatkan masyarakat melalui foto dan video yang kemudian di upload melalui media sosial instagram. Pemilihan media sosial instagram merupakan media online partisipatif yang memudahkan masyarakat memberikan masukan ataupun kritik pada kegiatan yang dilaksanakan. Media sosial adalah sarana yang merupakan medium berbasis teknologi internet (media online) yang memungkinkan seseorang dapat berinteraksi sosial, berkomunikasi dan berkerjasama, serta berbagi dengan orang lainnya (Kimbal, M, 2018).

\section{ISI}

Desa Sukamulti Kecamatatan Katapang Kabupaten Bandung, terdiri dari 16 Rukun Warga (RW) dan 32 Rukun Tetangga (RT) merupakan wilayah yang berbatasan dengan sungai citarum dan dilewati oleh anak sungai citarum. Desa Sukamukti mempunyai visi "Melalui kebersamaan, kita jadikan SUKAMUKTI menjadi desa yang berwawasan lingkungan, menjunjung tinggi kredibilitas, transparan serta akuntable dalam seluruh pelaksanaan kegiatan". Mayoritas Masyarakat beragama Islam dan bermata pencaharian sebagai petani maka tidak mengherankan jika wilayah Desa Sukamukti merupakan penghasil padi dan sayuran yang cukup baik jika di bandingkan dengan desa-desa yang ada di kecamatan katapang. Desa Sukamukti terdiri dari beberapa kampung diantara Kampung Pasantren, 
Cibogo, Cembul, Cangkudu, Landean yang dilewati oleh anak sungai citarum dan Kampung Bojong dan Cembul berbatasan langsung dengan Sungai Citarum yang menjadikan jika Sungai Citarum meluap akses ke Kota Bandung menjadi terputus. Permasalahan yang dihadapi Desa Sukamukti adalah dalam melakukan kampanye pemeliharaan Sungai Citarum sebagai berikut:

1. Keterbatasan kualitas kerja karena pendidikan relawan terbatas.

2. Keterbatasan dana untuk membuat program kampanye

3. Keterbatasan pengetahuan untuk membuat kampanye.

4. Belum mempunyai media untuk mendukung kampanye.

5. Belum mempunyai aplikasi interaktif untuk mendukung kampanye.

Kegiatan yang dilaksanakan 2-9 Agustus 2018 ini berbentuk workshop pembuatan konten video dan foto Program Citarum Harum, Penandatangan deklarasi Citarum Harum ini dihadiri oleh peserta terdiri dari perwakilan RT, RW, Karang Taruna Desan dan Karang Taruna RW dengan bertempat di Balai Desa Sukamukti Kecamatan Katapang Kabupaten Bandung. Para peserta workshop mendapat pemaparan dari para pembicara, serta pelatihan berupa praktik dan teori.

Teori dan praktek kegiatan ini meliputi materi dasar media Kampanye Pemberian materi foto dan Video, Pemberian materi website Penandatangan, Deklarasi Citarum Harum dan Diskusi.

Pelatihan Kampanye Pemeliharaan Aliran Sungai Citarum Di Desa Sukamukti menitikberatkan kepada bagaimana masyarakat memahami dan dapat membuat konten kampanye dengan bahasa dan konten yang dapat dimengerti oleh masyarakat sekitarnya. Untuk itu pihak Universitas Telkom memberikan materi dari mulai pemilihan bahasa, gambar dan video yang baik untuk media kampanye, selain itu juga selain luarannya berbentuk foto maupun video, materi kampanye diupload di instagram yang kemudian pada tanggal 1 November 2018 diumumkan pemenang hasil karya pembuatan karya kampanye lomba berbentuk video maupun foto.

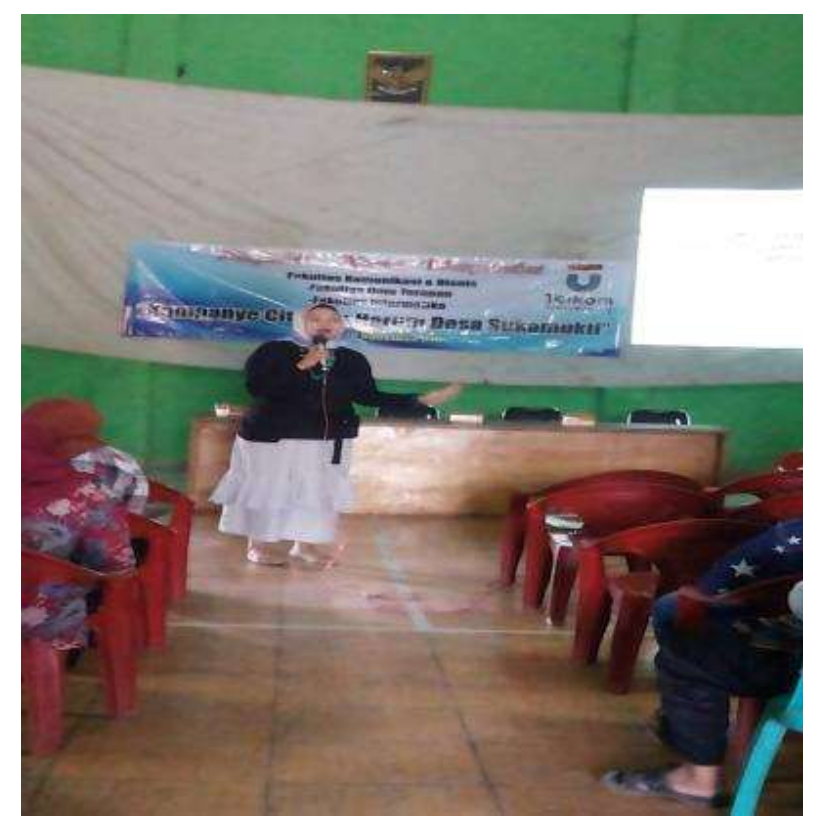

Foto 2.1 Foto Kegiatan Sosialisasi dan Workshop Media Kampanye 
Selain pemberian materi bagaimana membuat media kampanye melalui foto dan video secara efektif dan menarik termasuk faktor-faktor apa saja yang harus ada pada media kampanye (content), pada kegiatan ini dilakukan penandatangan dan penyerahan deklarasi pemeliharaan Sungai Citarum oleh warga Desa Sukamukti. Deklarasi yang berisi 4 point penting dalam menjaga kebersihan Sungai Citarum ini adalah:

\section{DEKLARASI DESA SUKAMUKTI}

Kami Warga Desa Mendeklarasikan Diri Untuk:

Mendukung Kampanye Citarum Harum

1. Tidak akan membuang sampah sembarangan

2. Menolak membuang sampah ke sungai

3. Menjaga kebersihan sungai citarum

4. Mengutuk pembuangan limbah beracun ke sungai citarum

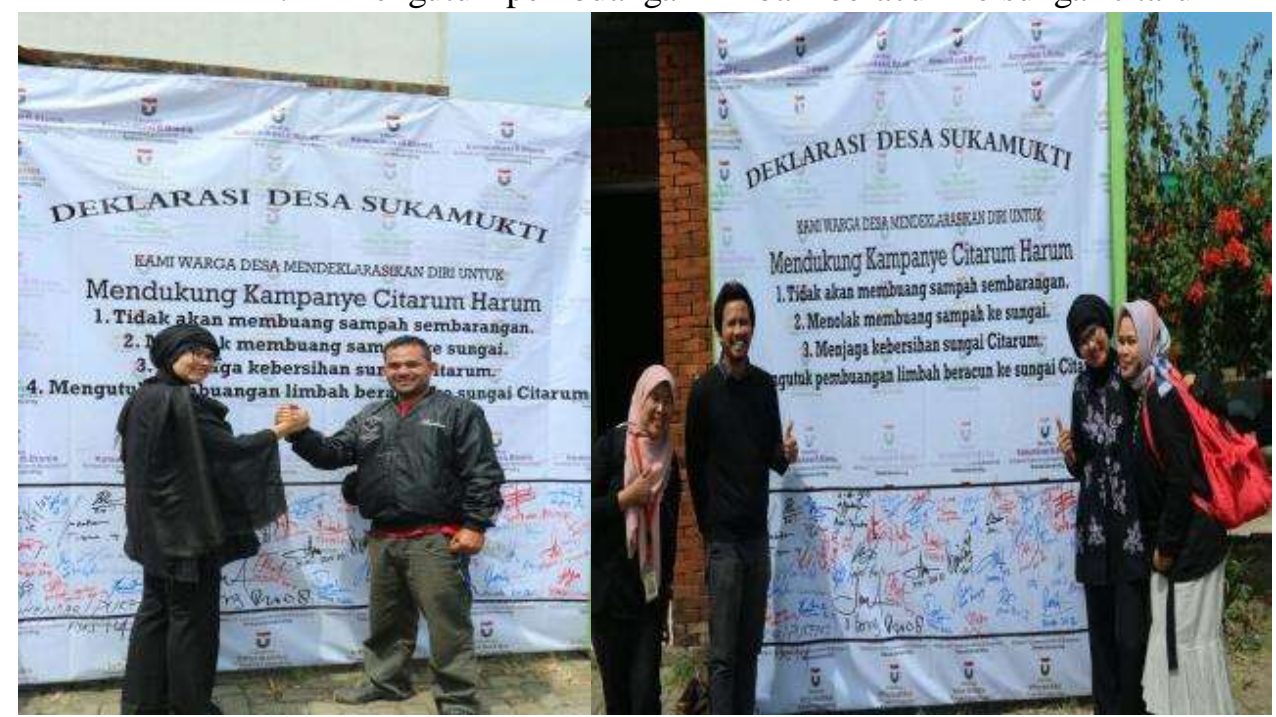

Foto 2.2 Foto Penandatanganan Deklarasi Warga Desa Sukamukti

Program Pengabdian Masyarakat dapat dievaluasi dengan hasil karya foto dan video masing-masing RW yang dilombakan dengan memberikan imbalan berupa uang tunai dan piala. Hal ini dimaksudkan agar masyarakat mempunyai partisipasi yang tinggi untuk membuat dan mendokumentasikan kegiatan dan komitmen masing-masi Rukun Warga yang ada di Desa Sukamukti.

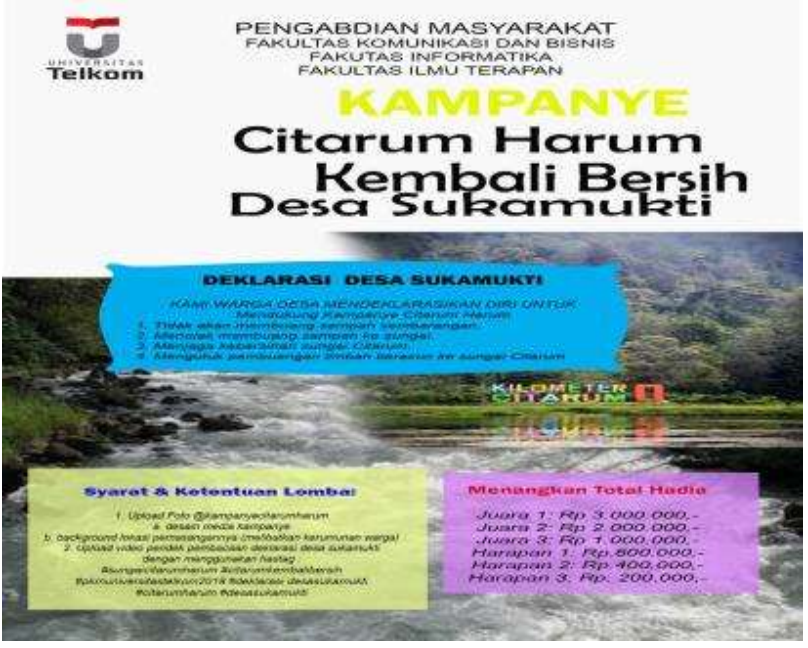

Foto 2.3 Foto Poster Lomba Media Kampanye 
Hasil karya kampanye video dan foto diupload ke instagram @kampanyecitarumharum / Off PKM Desa Sukamukti - TelU. Pembuatan Hasil Karya ini diberikan waktu 2 bulan agar dapat menghasilkan karya foto dan video yang sesuai dengan kriteria dan ketentuan lomba yaitu:

1. Foto/video diupload ke instagram @kampanyecitarumharum / Off PKM Desa Sukamukti TelU

2. Background lokasi pengambilan foto/video melibatkan kerumunan warga

3. Foto/video yang diupload menggunakan hastag sesuai dengan lomba

Alasan memilih instagram sebagai media yang digunakan untuk warga yang berpartisipasi untuk mengumpulkan hasil karya foto dan video karena menguntungkan masyarakat karena dapat melihat secara langsung kampanye yang dilakukan dengan foto maupun video yang menarik, memuat informasi secara lengkap dan detail melalui isi gambar dan Fasilitas Hashtag (tanda pagar) untuk memudahkan masyarakat.

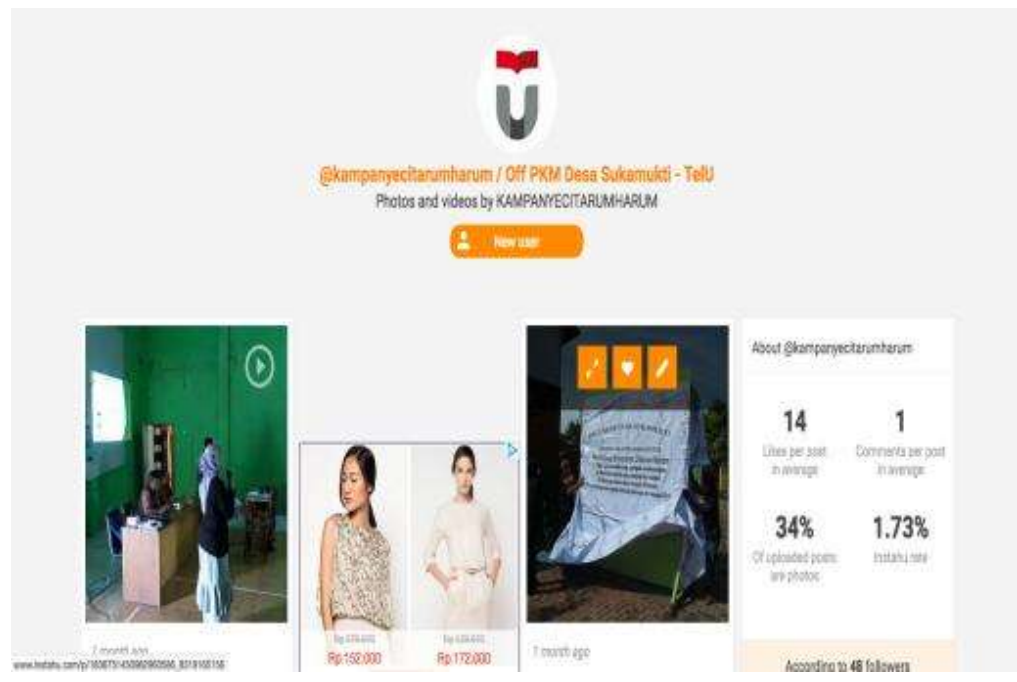

Foto 2.4

Foto Instagram @kampanyecitarumharum / Off PKM Desa Sukamukti - TelU

Setelah hasil karya foto dan video terkumpul kemudian dilakukan penjurian oleh tim dengan menggunakan kriteria penilaian foto dan video menampilkan tema yang belum pernah dilakukan oleh orang/kelompok lain, concep dan content sesuai dengan kriteria pengambilan foto dan video, selain itu juga like terbanyak dan menambahkan hastag yang ditetapkan dalam kriteria foto dan video menjadi faktor utama dalam pemilihan karya terbaik. Berikut adalah foto dan video yang mendapat penghargaan sebagai karya terbaik yang dihasilkan masyarakat melalui aktivitas kebersihan yang dilakukan di masing-masing lokasi Rukun Tetangga (RT) dan Rukun Warga (RW) sebagai komitmen menjaga kebersihan yang dimulai dari lingkungan tempat tingga mereka 


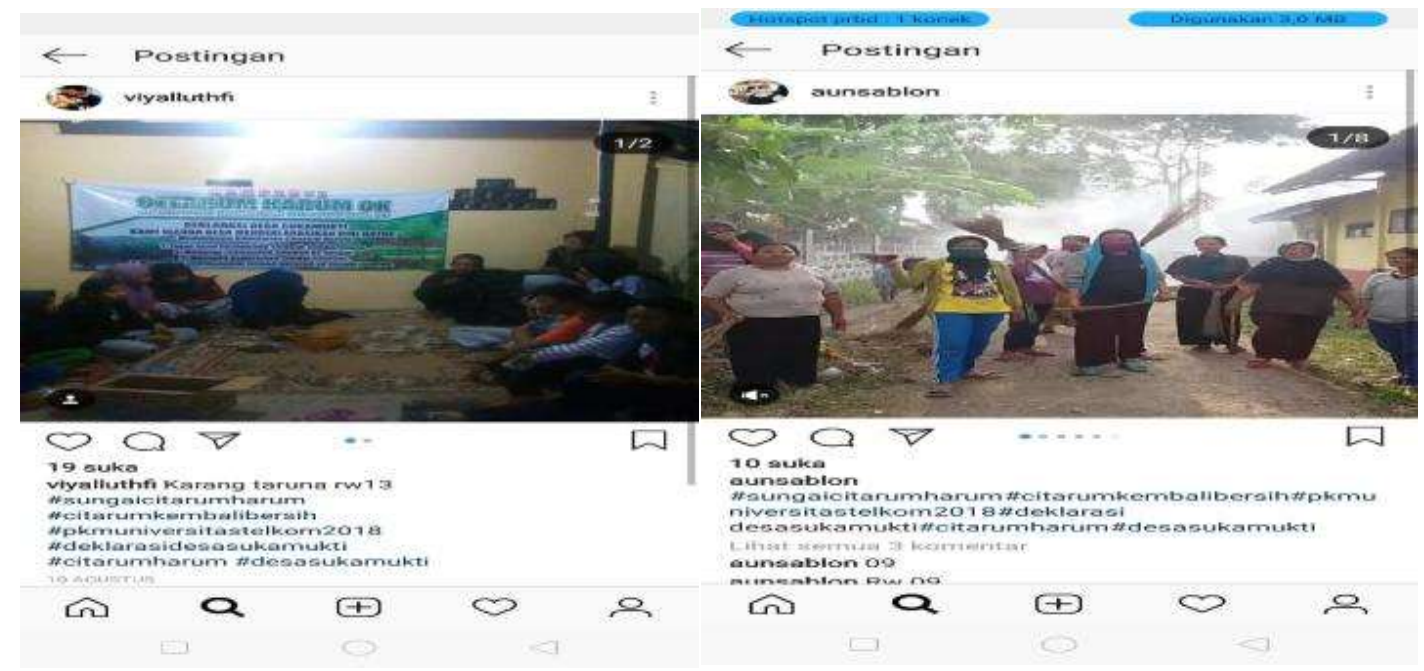

Foto 2.5 Foto kegiatan kebersihan yang menjadi Pemenang Media Kampanye

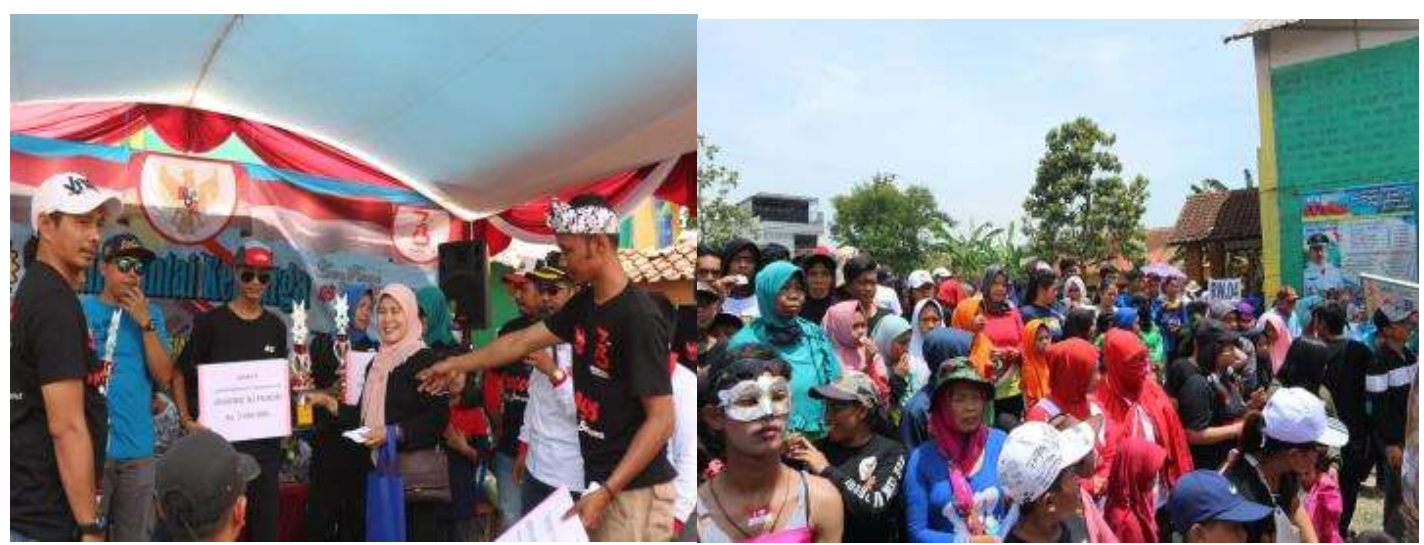

Foto 2.6 Foto kegiatan Pembagian piala dan Hadiah Media Kampanye

\section{SIMPULAN}

Kegiatan pemberdayaan masyarakat ini memiliki potensi kampanye yang baik. Kampanye yang melibatkan semua stakeholder dan didukung teknologi informasi perlu dijadikan alternatif solusi. Melalui kegiatan Pengabdian Masyarakat ini diharapkan bisa meningkatkan kesadaran warga, pemerintah, komunitas, perusahaan untuk bersama mengembalikan CItarum sebagai sungai yang ideal.

Media Kampanye foto dan video merupakan media yang sangat efektif dalam mensosialisasikan program kampanye pemeliharan aliran Sungai Citarum dan pemilihan instagram sebagai media hasil karya juga sangat efektif dengan berbagai keunggulan yang diberikan instagram yang hasil dan karya dapat diakses masyakat sehingga dapat memberikan partisipasi dalam bentuk karya atau komentar mengenai kegiatan yang akan atau sudah dilakukan. 


\section{UCAPAN TERIMAKASIH}

Dengan terlaksanakannya kegiatan ini, ijinkan penulis berterimakasih kepada pihakpihak yang telah memberikan support secara moril dan materil LPPM Universitas Telkom, Dekan Fakultas Komunikasi dan Bisnis Ade Irma Susanty, Ph.D, Wakil Dekan Fakultas Komunikasi dan Bisnis Dr. Syariffudin, Kaprodi Ilmu Komunikasi Freddy Yusanto, M.Ds, Kepala Desa Sukamukti Agus Tajudin, S. Pd dan masyarakat Desa Sukamukti yang telah berpartisipasi dalam Kegiatan Pengabdian Masyarakat.

Terimkasih yang tidak terhingga atas bantuan dan partisipasi kepada anggota tim pengabdian masyarakat Idola Perdini Putri, S.Sos., M.Si, Ratih Hasanah S.Sos., M.Si, Dini Salmiyah Fithrah Ali, S.S.,M.Si, Gede Agung Ary Wisudiawan, S.Kom, M.T., Yuyun Siti Rohmah, ST.,MT, Ira Dwi Mayangsari, M.M sehingga kegiatan ini dapat dilaksanakan dengan lancar dan semoga kegiatan ini dapat dilanjutkan dilanjutkan kedepannya dengan menggarap lokasi lain yang membutuhkan kegiatan ini.

\section{DAFTAR PUSTAKA}

Bksdajabar (2018). Presiden Jokowi Mengajak Bersama- sama Sembuhkan Citarum. Dipetik November 12, 2018, dari http://bbksdajabar.ksdae.menlhk. go.id/wp-content/uploads/2018/02/Sipers_ _Presiden_Canangkan_Restorasi_Ekosistem_DAS_Citarum.pdf

Cangara, Hafied. 2011. Komunikasi Politik Konsep, Teori, dan Strategi. Jakarta: PT. Raja Grafindo Persada.

Greenpeace (2018). Citarum Nadiku Mari Rebut Kembali. Dipetik November 12, 2018, dari http://www.greenpeace.org/seasia/id/campaigns/toxics/Air/citarum/

Indonesia Baik (2018). Jadikan Citarum Harum. Dipetik November 12, 2018, dari http://www.indonesiabaik.id/infografis/jadikan-citarum-harum

Kimbal, M. (2018). Partisipasi Politik dalam Proses Pembangunan Desa di Kecamatan Wori Kabupaten Minahasa Utara. Sosiohumaniora, 20(3), 282-287.

Sindo (2018). 10 Problem Besar Lingkungan di Indonesia. Dipetik Oktober 6, 2018, dari https://nasional.sindonews.com/read/1302781/15/10-problem-besar-lingkungan-diindonesia-1525347778/15

Tirto (2018). Tidak Membuang Sampah ke Sungai Kunci Utama Revitalisasi Citarum. Dipetik November 13, 2018, dari https://tirto.id/tidak-membuang-sampah-ke-sungai-kunciutama-revitalisasi-citarum

Venus, Antar. (2010) Manajemen Kampanye Detakan pertama 2004, Simbiosa Rekatama Media. 